\title{
Cara Mengajarkan Doktrin kepada Jemaat di Gereja
}

\author{
Pestaria Happy Kristiana \\ Sekolah Tinggi Alkitab Jember \\ pestaria_251273@yahoo.co.id
}

\begin{abstract}
This subject is important because, the teaching and learning process in the church tends to stagnate or not interesting. For this reason a strategy or pattern is needed so that the teaching and learning process can run well. Determining an effective pattern of doctrinal teaching requires proper understanding of how learners learn. Because to be able to form effective teaching patterns need to understand how adults learn and mix them in the form of an effective learning process. From the discussion, it was found that to determine the effective teaching pattern about doctrine for adults is: the teacher understands accurately about the needs of students. Teachers must be able to find various truths that are needed by students. Knowing the Bible as a real need must be an emphasis on effective learning patterns. Finally, adults need space to share experiences not to be filled with a variety of knowledge. Therefore, the teacher must be able to bridge the knowledge and experience in the process of learning and teaching that takes place.
\end{abstract}

Keywords: adult learning; doctrine; teaching patterns

\begin{abstract}
Abstrak
Pokok bahasan ini menjadi penting dikarenakan proses belajar mengajar di dalam gereja cenderung mengalami stagnasi atau tidak menarik. Untuk itulah diperlukan suatu strategi atau pola yang tepat agar proses belajar mengajar dapat berjalan dengan baik. Penentuan suatu pola pengajaran doktrin yang efektif memerlukan pemahaman yang tepat tentang bagaimana peserta didik belajar. Karena untuk dapat membentuk pola pengajaran yang efektif perlu memahami bagaimana orang dewasa belajar serta meramunya dalam bentuk sebuah proses belajar yang efektif. Dari pembahasan tersebut di dapatkan bahwa untuk menentukan pola mengajar efektif tentang doktrin bagi orang dewasa adalah: pengajar memahami secara akurat tentang kebutuhan peserta didik. Pengajar harus mampu menemukan barbagai kebenaran yang sangat dibutuhkan oleh peserta didik. Mengenal Alkitab sebagai sebuah kebutuhan nyata haruslah menjadi penekanan pada pola pembelajaran efektif. Akhirnya, orang dewasa membutuhkan ruang untuk berbagi pengalaman bukan untuk dipenuhi dengan berbagai ilmu pengetahuan. Oleh karena itu, pengajar harus bisa menjembatani antara pengetahuan dan pengalaman dalam proses belajar dan mengajar yang berlangsung.
\end{abstract}

Kata Kunci: doktrin; pembelajaran orang dewasa; pola pengajaran 


\section{PENDAHULUAN}

Pengajaran adalah suatu aktivitas (proses) belajar-mengajar. Di dalamnya ada dua subyek yaitu guru dan peserta didik. Guru sebagai yang mengendalikan, memimpin, dan mengarahkan event pengajaran. Guru disebut sebagai subyek (pelaku-pemegang peranan pertama) pengajaran. Oleh sebab itu ia menjadi pihak yang memiliki tugas, tanggung jawab dan inisiatif dalam proses pengajaran. Sedangkan murid sebagai orang yang terlibat langsung dalam proses pembelajaran. Karenanya dituntut keaktifan dalam proses pengajaran. Peserta didik disebut obyek pengajaran kedua, karena pengajaran itu tercipta setelah ada beberapa arahan dan masukan dari obyek pertama (guru) selain kesediaan dan kesiapan peserta didik itu sendiri sangat diperlukan untuk terciptanya proses pengajaran.

Pengajaran yang tepat sangat diperlukan mengingat adanya krisis yang tengah menghadang kekristenan sebagaimana diungkapkan oleh Carl Henry "Generasi kita telah kehilangan kebenaran Allah, realitas pewahyuan Ilahi, isi kehendak Allah, otoritas Firman Allah dan kuasa penebusannya. Kehilangan seperti ini membuat kekristenan harus membayar mahal. Karena mereka begitu cepat jatuh ke dalam kemurtadan dan meninggalkan Kristus."1

Gereja telah banyak melakukan pengajaran-pengajaran yang bersifat doktrin. Baik dalam bentuk Komsel maupun pendalaman Alkitab. Pelajaran ini dilakukan dalam jangka waktu tertentu. Bisa satu bulan satu kali, atau triwulan tergantung dari kebutuhan gereja setempat. Pengajar-pengajar dalam pendalaman Alkitab ini adalah hamba-hamba Tuhan yang berkompeten untuk menjelaskan tentang doktrin-doktrin Kristen. Namun pengajaran yang disampaikan menjadi "membosankan" hal ini dikarenakan tidak integrasikan dengan kehidupan nyata. Sebagaimana diungkapkan oleh Lois Lebar "Pengajaran Alkitab jarang diintegrasikan secara dinamis dengan kehidupan."2

Kebutuhan dunia akan hal-hal rohani lebih besar dari waktu sebelumnya. Hal ini dapat terlihat dari banyaknya penduduk dunia yang belum mengenal Yesus Kristus sebagai Tuhan dan juruslamat. Sementara itu, Amanat Agung di dalam Matius 28:18-20 adalah merupakan perintah kepada seluruh pendidik di dunia. Kita diperintahkan untuk menjadikan segala bangsa murid Yesus. Bagaimana caranya? Melalui pengajaran, yaitu mengajar orang-orang untuk mentaati semua yang diperintahkan Kristus kepada kita. Perintah-perintah tersebut salah satunya adalah doktrin kekristenan.

\footnotetext{
${ }^{1}$ Carl F.H. Henry, Twilight of a Great Civilization: The Drift Toward Neo-Paganism (Westchester, Ill: Crossway, 1988), 15

${ }^{2}$ Lois E. Lebar, Education That is Christian, Terj. Jeffrey Tanalessy (Malang: Gandum Mas, 2006), 13
} 
Selanjutnya, segmen besar yang juga perlu mendapatkan perhatian adalah orangorang Kristen lahiriah. Winter menyatakan "antara 25-35\% populasi dunia yang mengaku sebagai orang Kristen, sekurang-kurangnya satu milyar orang adalah orang Kristen lahiriah. ${ }^{3}$ Mereka adalah orang-orang yang paling tidak hidup dalam budaya Kristen sehingga lebih terbuka terhadap pengajaran Alkitab. Sehingga ada kebutuhan mendesak akan pengajaran Alkitab yang mengubah kehidupan bagi orang-orang Kristen lahiriah.

Di samping itu, pada masa kini gereja tidak kekurangan pengajar Alkitab untuk menyatakan prinsip-prinsip doktrin Kristus secara benar, namun banyak di antara mereka merasa puas hanya dengan mengajar pokok-pokok iman selama bertahun-tahun, anehnya mereka tidak menyadari tidak adanya manifestasi kehadiran Allah dalam pelayanan mereka, tidak pula sesuatu yang luar biasa dalam kehidupan mereka pribadi mereka. Mereka tetap menggembalakan (melayani) orang-orang percaya, yang merasakan suatu kerinduan yang dalam untuk suatu pembelajaran. Sementara para pengajar tidak mampu memberikan pengajaran yang benar-benar dapat memuaskan kerinduan mereka. ${ }^{4}$

Karenanya, tulisan ini beranjak dari sebuah pertanyaan bagaimana pola pengajaran doktrin yang efektif bagi jemaat masa kini? Dengan mengajukan pertanyaan apakah yang dimaksud dengan pola pengajaran, bagaimana pola pengajaran bagi orang dewasa? dan akhirnya bagaimana pola pengajaran doktrin bagi jemaat dewasa ini.

Pengajaran juga merupakan suatu proses yang sistematis dan sistemik yang terdiri atas banyak komponen. Masing-masing komponen pengajaran tidak bersifat parsial (terpisah) atau berjalan sendiri-sendiri, tetapi harus berjalan secara teratur, saling bergantung, komplementer dan berkesinambungan. Untuk itulah diperlukan pengelolaan pengajaran yang baik. Pengelolaan pengajaran yang baik ini, harus dikembangkan melalui pola pengajaran yang baik.

Berbicara tentang pola pengajaran maka kita tidak dapat lepas dari kata mengajar. Sidjabat $^{5}$ mengatakan ada tiga pengertian mengajar yaitu: pertama, mengajar sebagai upaya pengajar untuk mentransfer pengetahuan atau pandangan, keyakinan, dogma, doktrin atau teologia yang dimiliki kepada peserta didik. Kedua, mengajar sebagai usaha dari pengajar untuk menolong peserta didik sedemikian rupa sehingga dapat menemukan

\footnotetext{
${ }^{3}$ Ralp D. Winter, The Task Remaining: All Humanity in Mission Perspective," (Pasadena: William Carey Library, 1981), 321

${ }^{4}$ A.W. Tozer, The Pursuit Of God (Harrisburg,Pa: Christian Publication Inc., 1948), 8

${ }^{5}$ B.S. Sidjabat, Menjadi Guru Profesional: Sebuah Perspektif Kristiani, cet. 2 (Bandung: Yayasan Kalam Hidup, 2000), 7-9
} 
konsep diri secara benar. Ketiga, mengajar sebagai upaya pengajar untuk mengelola atau mengatur situasi sedemikian rupa sehingga peristiwa belajar dapat terjadi.

Berdasarkan penjelasan di atas maka pola pengajaran dapat diartikan sebagai model atau cara kerja yang digunakan dalam proses, cara, perbuatan mengajar atau mengajarkan. Sehingga dalam proses penjelasan selanjutnya penulis akan menggunakan kata pola pengajaran sama dengan model pengajaran.

\section{Pentingnya Pola Pengajaran}

Model-model pengajaran dapat juga dianggap sebagai model-model pembelajaran. Karena pada hakikatnya, saat kita membantu peserta didik untuk memperoleh informasi, gagasan, skill, nilai, dan cara berpikir, sebenarnya kita sedang mengajari mereka untuk belajar. Berdasarkan hal tersebut tidaklah menjadi salah jika dalam pembahasan selanjutnya kita akan banyak bergelut dengan model-model pengajaran atau model-model pembelajaran.

Seorang pendidik secara khusus pendidik di dalam lingkungan gereja sangatlah penting untuk memahami tentang model-model pengajaran. Hal ini dikarenakan ada beberapa alasan penting berkaitan dengan hal tersebut yaitu ${ }^{6}$ : Pertama, model pengajaran yang efektif meningkatkan kemampuan siswa dalam belajar. Kedua, model pengajaran dirancang untuk membantu peserta didik meningkatkan kekuatan mereka sebagai pembelajar. Saat mereka menguasai informasi dan ketrampilan, yang merupakan hasil dari setiap pengalaman belajar --- bukan hanya soal isi/materi pembelajaran yang dapat mereka pelajari --- maka hal itu juga meningkatkan kemampuan mereka untuk menyelesaikan tugas-tugas pembelajaran masa depan dan membuat program-program belajar untuk diri mereka sendiri. Ketiga, model pengajaran yang efektif sangat mempengaruhi gairah belajar dari peserta didik atau dengan kata lain memotivasi peserta didik untuk lebih giat dalam belajar.

Pentingnya pola pengajaran yang tepat dalam mengajarkan doktrin maka penting bagi kita untuk memahami adanya kecenderungan pola-pola pengajaran yang lebih menonjol yaitu:

Pertama, pola pengajaran yang menekankan pada faktor-faktor lahiriah. ${ }^{7}$ Maksudnya adalah ajaran-ajaran gereja telah turun derajatnya menjadi kuliah-kuliah formal dan Tanya jawab kateketis. Lalu dikembangkannya teologi untuk mengaitkan

\footnotetext{
${ }^{6}$ Bruce Joyce, Marsha Weil dan Emily Calhoun, Model-Model Pengajaran (Yogyakarta: Pustaka Pelajar, 2009), 7-10.

${ }^{7}$ Lois E. Lebar, Education That is Christian, Terj. Jeffrey Tanalessy (Malang: Gandum Mas, 2006), 45
}

Copyright(C) 2019, KHARISMATA, ISSN 2655-8645 (online), 2655-8653 (print) | 92 
doktrin Kristen dengan filsafat duniawi atau untuk menunjukkan pertentangannya, otoritas gereja dan organisasi dikembangkan untuk menstabilkan gereja. Akibatnya kita melihat bahwa dari abad ke abad pendidik kerap kali menganggap tugas mereka ialah memperkenalkan murid-murid kepada pokok faktual dan membuat mereka mampu menerangkan kembali pengetahuan lahiriah ini. Mereka mengandalkan, nyaris sepenuhnya pada cara penyampaian kebenaran secara lisan (verbal).

Kedua, pola pengajaran yang menekankan pada faktor-faktor bathiniah. Artinya lebih menekankan pengalaman hidup tanpa memperhatikan hal-hal yang bersifat teoritis. Akibatnya didapatkan pola pengajaran yang sangat relatif dan tergantung dari pengalaman bathiniah peserta didik. Lalu bagaimana seharusnya? Diperlukan pola pengajaran berikutnya

Ketiga, pola pengajaran yang memadukan keduanya. ${ }^{8}$ Artinya, tidak cukup hanya berkonsetrasi pada faktor-faktor lahiriah maupun faktor batiniah, melainkan juga mengintegrasikan keduanya. Sasarannya ialah kesalehan, moralitas, dan pengetahuan. ${ }^{9}$

\section{Pola Pengajaran Yesus}

Pola pengajaran yang berhasil adalah pola pengajaran yang individu-individunya dapat berubah dan bertumbuh dalam segala aspek kehidupan. Sepanjang pelayanannya Yesus melakukan pengajaran bagi para murid dan beberapa orang lainnya berikut beberapa pola pengajaran Yesus terutama cara yang dipakai saat melayani perempuan Samaria (Yohanes 4:1-42):

\section{Interaksi dengan Murid}

Seorang pendidik Kristen seharusnya mengawali pengajarannya dengan pertanyaan-pertanyaan seperti ini: Apakah kita langsung mendapatkan minat dan perhatian peserta didik? Apakah kita memulai pembelajaran di mana peserta didik berada, dan apakah kita berbicara kepada mereka mengenai kegiatan-kegiatan nyata mereka? Ataukah kita mengatakan,"Apa yang kita pelajari minggu lalu? Kenyataan yang ada banyak pendidik yang berpikir bahwa mengajar itu sama dengan menyajikan fakta-fakta Alkitab melalui situasi formal. Pendidik tidak berpikir tentang mengajar individuindividu melalui situasi-situasi nyata dalam hidup. Inilah salah satu alasan pokok mengapa pendidik tidak mendapatkan hasil seperti yang diinginkan.

\footnotetext{
${ }^{8}$ Agustin Soewitomo Putri, "Menstimulasi Kualitas Kehidupan Rohani Dalam Meningkatkan Kemandirian Belajar Mahasiswa : Studi Refleksi Daniel 6 : 1-4," DUNAMIS ( Jurnal Teologi dan Pendidikan Kristiani ) 1, no. 2 (2017): 55-70, www.sttintheos.ac.id/e-journal/index.php/dunamis.

${ }^{9}$ Harls Evan Rianto Siahaan, "Hikmat Sebagai Implikasi Pendidikan Kristiani Dalam Keluarga: Refleksi 1 Raja-Raja 3:1-15," DUNAMIS (Jurnal Teologi dan Pendidikan Kristiani) Vol 1, no. 1 (2016): 15-30, www.sttintheos.ac.id/e-journal/index.php/dunamis.
} 
Pendekatan ini sangat penting apabila akan melakukan sebuah pembelajaran. Sikap dari peserta didik pada permulaan menjadi faktor penentu. Jika peserta didik merasa mereka butuh dan mulai dengan minat serta perhatian yang kuat, momentum itu akan berpengaruh lama dan mereka akan terlibat secara aktif. Jika mereka acuh tak acuh.

\section{Melibatkan Anak Didik secara Aktif}

Mengajak anak didik terlibat secara aktif adalah melibatkan mereka dalam proses pembelajaran yang dapat menstimulasi atau membangkitkan rasa keingintahuannya. Keingintahuan itu membuat peserta didik terdorong untuk mengajukan pertanyaanpertanyaan yang ingin diketahuinya. Sehingga pada akhirnya, peserta didik meminta sendiri untuk diajar tentang materi pembelajaran tersebut.

Inilah yang menjadi tugas pendidik yaitu terus membimbing dan mengajak aktif peserta didik dalam proses pembelajaran. Terutama membawa hal-hal yang bersifat fisik (teoritis) kepada hal-hal yang bersifat bathiniah (rohani) dan kebutuhan yang dirasakan oleh peserta didik kepada kebutuhannya yang sejati. Memulai dari kebutuhan yang dirasa oleh anak didik tidak berarti membiarkan dia sendiri di sana mengatasi kebutuhannya, melainkan memimpin dia untuk merasakan kebutuhan rohaninya yang sejati, lalu menemukan jawaban terhadap kebutuhan itu melalui Firman Allah.

\section{Memenuhi Kebutuhan Rohani}

Memenuhi kebutuhan rohani yang sebenarnya mengandung pengertian memenuhi kebutuhan rohani yang sebenarnya dari peserta didik. Dengan kata lain, tidak hanya tentang teori-teori saja melainkan pada kebutuhan bathin yang mendasar. Mengapa hal ini penting? Karena sering di dapati pada umumnya pendidik mengucapkan kebenarankebenaran Firman Allah yang berharga ke udara. Maksudnya, pendidik mengajarkan suatu pelajaran yang tidak berkaitan sama sekali dengan yang sedang dikerjakan dan dipikirkan oleh anak-anak didik.

Banyak dari proses pembelajaran hanya sampai titik peserta didik mampu menghafal ayat Alkitab atau menceritakan kembali pelajaran yang telah mereka dapatkan dari gurunya. Lalu apa sebenarnya yang diharapkan terjadi dalam diri peserta didik? Perubahan hidup sebagai tindakan langsung. Artinya, peserta didik mengetahui sesuatu untuk dipergunakan di masa yang akan datang, sehingga dia dapat berubah pada hari itu juga serta memberikan respon yang pasti sekarang ini. Jika seseorang mengetahui kebutuhannya paling dalam dipenuhi oleh Firman Hidup dan oleh Alkitab, dia akan siap untuk datang kepada sumber yang sama keesokan harinya. 
Hal ini dikhususkan kepada mereka yang sudah memiliki pengetahuan tentang kebenaran Firman Allah. Hal yang pertama dilakukan adalah tetap melibatkan aktif peserta didik melalui tanya jawab yang berangkat dari kebutuhan mereka, sehingga pendidik dapat mengetahui sampai dimana terletak pemahaman mereka. Kemudian pendidik memberikan gagasan baru berdasarkan yang lama, kemudian membuat generalisasi dan menerapkannya. Tetapi pendekatannya bukanlah mengingat kembali suatu gagasan lama, tetapi mulai dengan kebutuhan pribadi peserta didik dan mengaitkan setiap bagian dari penjelasan dengan kebutuhan pribadi tersebut.

\section{Pendidikan kepada Orang Dewasa}

Pengajaran doktrin di dalam gereja secara umum biasanya diajarkan kepada mereka-mereka yang sudah termasuk kategori dewasa. Karena orang dewasa bukan anak kecil, maka pendidikan bagi orang dewasa tidak dapat disamakan dengan pendidikan pada anak-anak. perlu dipahami apa pendorong bagi orang dewasa belajar, apa hambatan yang dialaminya, apa yang diharapkannya, dan bagaimana ia dapat belajar paling baik. Untuk itulah pada bagian ini penulis akan membahas dua bagian besar yaitu belajar bagi orang dewasa dan bagaimana orang dewasa sebagai pelajar.

Telah disepakati bahwa belajar bagi orang dewasa berbeda dengan belajar bagi anak-anak. Ada beberapa penekanan yang penting untuk diperhatikan berkaitan dengan pembelajaran orang dewasa yaitu: ${ }^{10}$

Pertama, belajar bagi orang dewasa haruslah nampak pada perubahan prilaku. Artinya perubahan peri laku terjadi karena adanya perubahan (penambahan) pengetahuan atau ketrampilan. Dengan demikian, pendidikan bagi orang dewasa tidak cukup hanya dengan memberi tambahan pengetahuan tetapi harus ada perubahan peri laku.

Kedua, orang dewasa sudah mempunyai sikap tertentu, pengetahuan tertentu dan ketrampilan tertentu. Terkadang sikap tersebut sudah lama menetap pada dirinya sehingga tidak mudah untuk merubahnya. Juga pengetahuan yang selama ini dianggapnya benar dan bermanfaat belum tentu mudah digantikan dengan pengetahuan baru jika kebetulan tidak sejalan dengan yang lama. Karena itu, pembelajar orang dewasa haruslah terdorong oleh rasa tidak puas lagi dengan perilaku yang sekarang dan menginginkan perilaku yang baru.

Ketiga, pembelajaran bagi orang dewasa haruslah disesuaikan dengan kebutuhan mereka. Kebutuhan yang dimaksud adalah berhubungan dengan kehidupan mereka di masa kini. Sebagaimana dinyatakan oleh Lebar "Hanya Ketika murid-murid menyelidiki

${ }^{10}$ A.G. Lunandi, Pendidikan Orang Dewasa (Jakarta: P.T. Gramedia, 1984), 1-4. 
dan menemukan pesan atau isi Alkitab yang berhubungan dengan kehidupan masa kinilah yang akan memperkaya dan mengubah kehidupan mereka."11 Oleh karena itu diperlukan suatu upaya awal untuk mencari kebutuhan-kebutuhan apa yang mendasar yang diperlukan oleh orang dewasa.

Orang dewasa sebagai pelajar memiliki beberapa ciri yang harus diperhatikan dengan lebih mendalam yaitu ciri Fisiologis, Psikologi dan suasana belajar yang diinginkan. Secara Fisiologis hal yang paling pokok dapat menghambat keikutsertaan orang dewasa dalam suatu program pendidikan adalah faktor penglihatan dan faktor pendengaran. Sehingga diperlukan bahan ajar dengan tulisan yang agak besar, alat peraga dengan warna-warna yang lebih terang serta suara yang lebih lantang dan tidak terlalu cepat.

Dari segi psikologik orang dewasa dalam situasi belajar mempunyai sikap tertentu, maka perlu diperhatikan hal-hal berikut: orang dewasa bukanlah orang yang diajar melainkan orang dewasa yang dimotivasi untuk mencari pengetahuan baru, ketrampilan baru dan sikap yang baru. Orang dewasa belajar jika ia menemukan arti baru untuk memenuhi kebutuhannya. Belajar bagi orang dewasa itu adalah mengalami sesuatu yang bersifat pribadi yang berkaitan dengan proses emosional dan intelektual dengan cara mengalami sesuatu yang kesemuanya itu di dapat melalui proses bekerja sama satu dengan lainnya.

Suasana belajar bagi orang dewasa juga penting untuk diperhatikan diantaranya adalah suasana yang saling hormat-menghormati, harga-menghargai, suasana percaya. Suasana penemuan diri yaitu suasana yang memberikan kesempatan kepada orang dewasa untuk menemukan sendiri kebutuhannya, pemecahan masalahnya dan kesalahankesalahannya. Suasana tidak mengancam artinya orang dewasa harus mempunyai perasaan, bahwa dalam situasi belajar itu ia boleh berbeda dan boleh berbuat salah tanpa dirinya terancam. Suasana keterbukaan yaitu suasana terbuka untuk mengungkapkan diri, mendengarkan orang lain tanpa adanya ejekan, hinaan atau dipermalukan. Suasana mengakui kekhasan pribadi. Suasana yang mengijinkan adanya perbedaan pendapat. Suasana mengakui hak untuk berbuat salah yaitu suasana belajar yang mendorong orang dewasa mencoba prilaku baru. Sedang kan dalam perilaku baru mengandung suatu resiko terjadinya kesalahan. Maka kesalahan, kekeliruan adalah bagian yang wajar dari belajar. Suasana keraguan dan pada akhirnya adalah suasana untuk mampu mengevaluasi bersama dan mengevaluasi diri sendiri.

\footnotetext{
${ }^{11}$ Lois E. Lebar, Education That is Christian, Terj. Jeffrey Tanalessy (Malang: Gandum Mas, 2006), 10
} 
Pendekatan pembelajaran bagi orang dewasa lebih berpola non otoriter atau pola persuasif, bersifat informal yang memberikan rasa aman, fleksibel dan tidak mengancam dalam proses pembelajaran. Sedangkan ruang lingkup pembelajaran orang dewasa mencakup pencarian terbaru tentang makna kehidupan. Oleh karena itu, pembelajaran orang dewasa dimulai dari memberikan perhatian pada masalah-masalah yang terjadi/ ditemukan dalam kehidupannya. ${ }^{12}$ Dengan demikian pembelajaran orang dewasa efektif manakala berkaitan dengan kebutuhan, situasi kehidupan, pengalaman hidup, konsep diri dan memperhatikan perbedaan antar individu peserta didik.

Tujuan umum dari pembelajaran orang dewasa adalah untuk membantu peserta didik sebagai orang dewasa yang menjalankan peran sosialnya di masyarakat secara bertanggung jawab, sehingga diperoleh rasa percaya diri, mempunyai kemampuan mandiri guna berperan aktif dalam proses pembelajaran.

\section{PEMBAHASAN}

Pengajaran Doktrin adalah pengajaran yang sifatnya adalah mengajarkan tentang konsep-konsep yang didasarkan pada Alkitab yaitu konsep tentang Alkitab, Allah, Manusia, Kristus, Roh Kudus, Gereja dan Akhir zaman. Pengajaran ini akan terasa berat jika tidak menggunakan pola pengajaran yang tepat. Lalu Bagaimana membuat sebuah pola pengajaran yang tepat?

Pertama, pola pengajaran yang mengadakan kontak dengan murid atau dengan kata lain sesuai dengan kebutuhan murid. Untuk itu diharapkan seorang pendidik sebelum mengajarkan pokok-pokok doktrin kekristenan terlebih dahulu memahami tentang kebutuhan dari peserta didiknya. Bagaimana caranya? Dengan membuat catatan mengenai perhatian mereka, minat mereka dan persoalan-persoalan hidup yang dapat dikaitkan secara lebih baik dengan Firman Allah yang berotoritas. Catatan ini akan dapat diperoleh jika pendidik bergaul akrab dengan peserta didiknya dan memiliki kemampuan untuk membahasakan pertanyaan-pertanyaan pribadi sehingga dapat dengan mudah dimengerti oleh peserta didik. Selain itu, para pengajar perlu menjadi trampil dalam menghubungkan berbagai kebutuhan para murid dengan ayat-ayat Alkitab yang memenuhi berbagai kebutuhan itu.

Kedua, pola pengajaran dimana pendidik menyediakan situasi mengajar bagi para siswa dan membimbing mereka dalam menemukan berbagai kebenaran yang sangat penting. Pendidik harus mampu menolong peserta didik untuk mempelajari tokoh-tokoh

\footnotetext{
${ }^{12}$ Handreas Hartono, "Kurikulum PAK Yang Kontekstual Bagi Usia Lanjut Dan Aktual," KURIOS (Jurnal Teologi dan Pendidikan Agama Kristen) 1, no. 1 (2013): 11-21, www.sttpb.ac.id/ejournal/index.php/kurios.
} 
Alkitab atau doktrin-doktrin sesuai dengan konteks para tokoh tersebut. Kemudian peserta didik dibimbing untuk menarik berbagai prinsip dari apa yang dipelajarinya yang kemudian diterapkan dalam kehidupan sehari-harinya.

Ketiga, pola pengajaran yang membawa peserta didik untuk mengenal Kitab Suci secara mendalam. Seorang pribadi perlu terlibat dalam mempelajarinya sebelum Kitab Suci menjadi bagian dari hidupnya, sampai ia hidup di dalamnya dan Kitab Suci hidup di dalamnya.

Keempat, Pola pengajaran yang tidak memulai dengan pengetahuan, tetapi dengan pangalaman. Kecuali bila para murid kita merasakan sebuah kebutuhan. Para murid menceritakan pengalaman mereka ketika menghadapi suatu persoalan dan bagaimana tindakan mereka mengatasi persoalan tersebut. Kemudian dibahas dengan bersama-sama apa kata Alkitab (tentunya dikaitkan dengan doktrin) tentang hal tersebut. Tindakan apakah yang harus kita ambil? Apakah yang harus kita perbuat? Bagaimanakah kita akan menanggapi Allah sepanjang minggu ini? Dapatkah kita melihat diri kita sedang mentaati perintahNya? Dll.

Akhirnya, proses pembelajaran yang diharapkan dapat memberikan ruang yang "Memanusiakan" orang dewasa. Maksudnya adalah tidak hanya memberikan kepada mereka konsep-konsep yang harus dipelajari dan dihafal melainkan mengikutsertakan mereka dalam membangun konsep tersebut. Hal ini dapat dilakukan dengan memberikan suasana belajar yang dapat memberikan kesempatan untuk memberikan pendapat dan berpendapat beda tanpa harus takut akan konsekwensi dari perbedaan tersebut.

\section{KESIMPULAN}

Pengajaran doktrin adalah pengajaran yang penting untuk membangun iman jemaat berkaitan dengan pemahaman mereka tentang konsep-konsep dasar Kekristenan. Untuk itu diperlukan suatu pola pengajaran yang menekankan pada pendekatan kepada murid (kontak dengan murid). Hal ini dapat dilakukan dengan cara mengajar yang berangkat dari kebutuhan murid. Berikutnya pola pengajaran yang mengajak anak didik terlibat secara aktif. Keterlibatan ini dapat dilakukan dengan membawa murid untuk terlibat dalam proses tanya jawab yang berkaitan dengan materi pembelajaran. Selanjutnya, adalah pola pengajaran yang memenuhi kebutuhan rohani dari murid, maksudnya adalah menyentuh persoalan yang sebenarnya dari peserta didik. Dan akhirnya, pola pengajaran yang menolong peserta didik untuk melakukan kebenaran yang diajarkan. 


\section{REFERENSI}

A.G. Lunandi, Pendidikan Orang Dewasa (Jakarta: P.T. Gramedia, 1984)

A.W. Tozer, The Pursuit Of God (Harrisburg,Pa: Christian Publication Inc., 1948)

Bruce Joyce, Marsha Weil dan Emily Calhoun, Model-Model Pengajaran (Yogyakarta: Pustaka Pelajar, 2009)

Carl F.H. Henry, Twilight of a Great Civilization: The Drift Toward Neo-Paganism (Westchester, Ill: Crossway, 1988)

Hamzah B.Uno, Model Pembelajaran, Ed. 1, Cet. 8 (Jakarta: Bumi Aksara, 2011)

Hartono, Handreas. "Kurikulum PAK Yang Kontekstual Bagi Usia Lanjut Dan Aktual." KURIOS (Jurnal Teologi dan Pendidikan Agama Kristen) 1, no. 1 (2013): 11-21. www.sttpb.ac.id/e-journal/index.php/kurios.

Kamus Bahasa Indonesia Online

Lois E. Lebar, Education That is Christian, Terj. Jeffrey Tanalessy (Malang: Gandum Mas, 2006),

Putri, Agustin Soewitomo. "Menstimulasi Kualitas Kehidupan Rohani Dalam Meningkatkan Kemandirian Belajar Mahasiswa : Studi Refleksi Daniel 6 : 14." DUNAMIS ( Jurnal Teologi dan Pendidikan Kristiani ) 1, no. 2 (2017): 55-70. www.sttintheos.ac.id/e-journal/index.php/dunamis.

Ralp D. Winter, The Task Remaining: All Humanity in Mission Perspective," (Pasadena: William Carey Library, 1981)

Siahaan, Harls Evan Rianto. "Hikmat Sebagai Implikasi Pendidikan Kristiani Dalam Keluarga: Refleksi 1 Raja-Raja 3:1-15.” DUNAMIS (Jurnal Teologi dan Pendidikan Kristiani) Vol 1, no. 1 (2016): 15-30. www.sttintheos.ac.id/ejournal/index.php/dunamis.

Walter Dick \& Lou Carey, The Systematic Design of Instruction, fourth Edition, (New York: Harper Collins College Publiser, 1996)

Wayne Grudem,Systematic Theology: An Introduction to a Biblical Doctrine (G. R. Michigan: Zondervan Pub. House, 1994). 